\title{
Serum ferritin level in transfusion dependent $\beta$-thalassaemia patients in Mosul
}

\author{
Faris Y. Bashir, Omar A. Sadoon \\ Department of Pathology, College of Medicine, University of Mosul.
}

(Ann. Coll. Med. Mosul 2010; 36 (1 \& 2): 72-78).

Received: $10^{\text {th }}$ Jan 2010; Accepted: $10^{\text {th }}$ Nov 2010.

\begin{abstract}
Objectives: To establish a correlation between serum ferritin and different clinical, biochemical and haematological parameters and to determine the efficacy of chelation therapy using desferrioxamine measured by serum ferritin.
\end{abstract}

Patients and Methods: A case-series of one hundred patients with transfusion dependent $\beta$-thalassaemia were included in the study during a period of one year (Nov. 2007-Nov.2008). The study included clinical evaluation, routine haematological tests and serum ferritin level.

Results: Mean value of serum ferritin in our patients was $1886.74 \mathrm{ng} / \mathrm{ml}$. It was found that serum ferritin was higher in older patients, those who received higher number of blood transfusions to date and those of higher annual blood consumption. $\beta$-thalassaemic patients with serum ferritin level equal or higher than $2500 \mathrm{ng} / \mathrm{ml}$ were older, of shorter stature, had higher percentage of splenectomy, higher number of blood transfusions to date and higher annual blood consumption than patients with serum ferritin level less than $2500 \mathrm{ng} / \mathrm{ml}$. It was found that patients with good compliance to chelation therapy with desferrioxamine had lower mean serum ferritin than patients with poor compliance. Thirty seven percent of our patients had growth retardation regarding weight for age and $57 \%$ were low in height for their age.

Conclusions: Serum ferritin was higher in older patients, those with higher annual blood consumption and those with poor compliance to desferrioxamine therapy when compared to patients with good compliance. Patients with serum ferritin equal to or more than $2500 \mathrm{ng} / \mathrm{ml}$ were older and of shorter stature for their age than patients with serum ferritin less than $2500 \mathrm{ng} / \mathrm{ml}$.

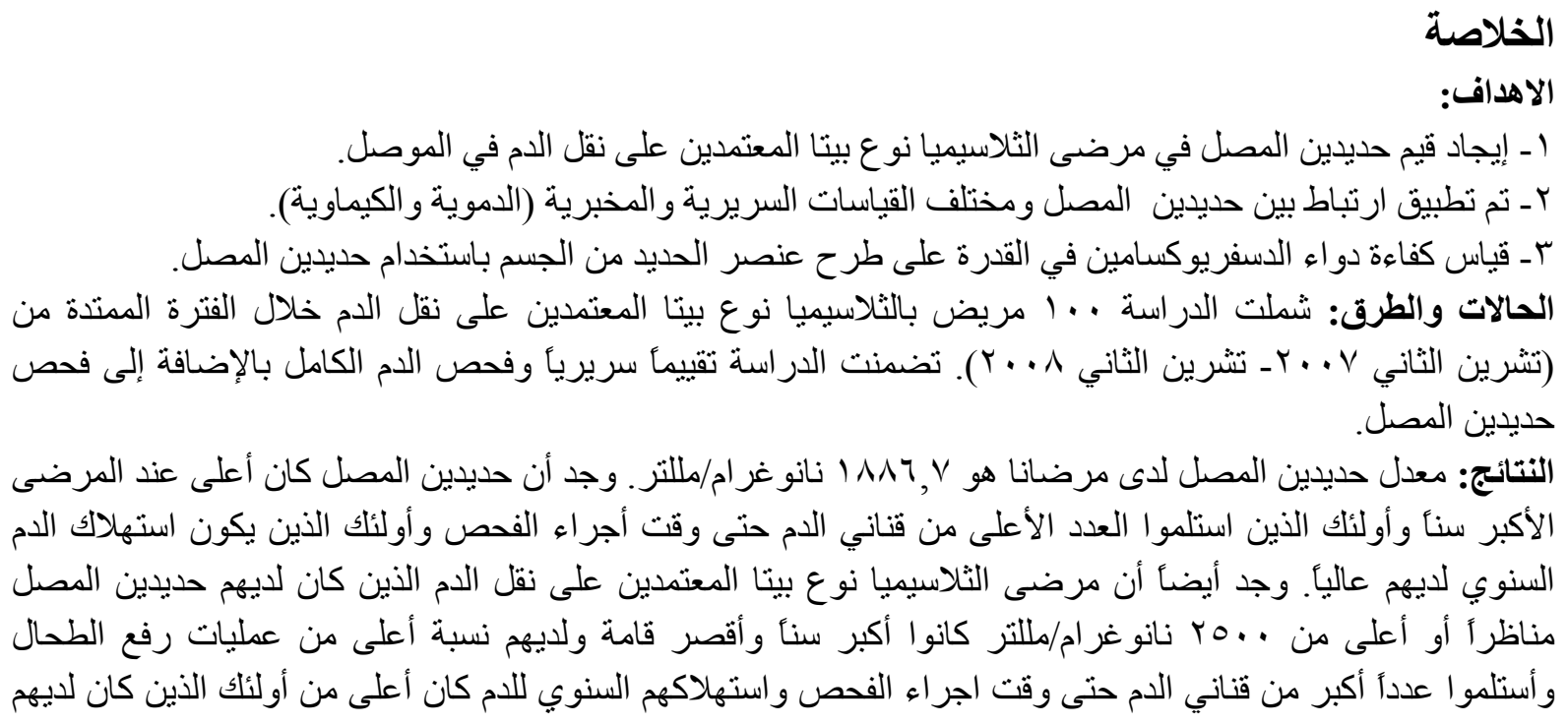




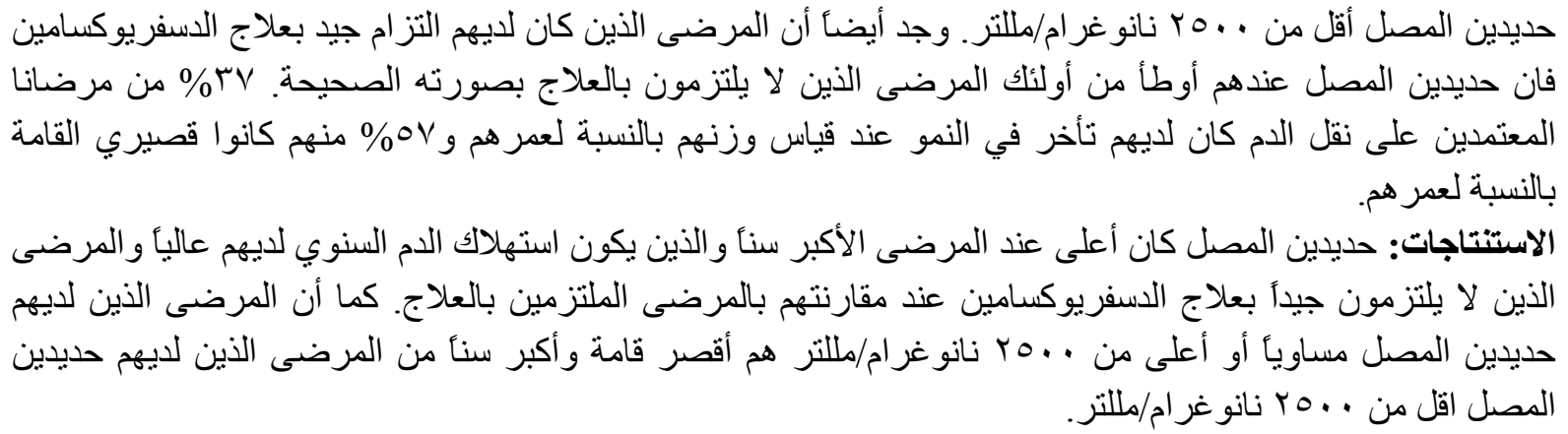

$\mathrm{T}$ halassaemia is the commonest single gene disorder in man, characterized by a lack or decreased synthesis of one or more of the globin subunits of haemoglobin molecule (1). $\beta$-thalassaemia is classified into $\beta^{0}$ thalassaemia with complete absence of $\beta$ globin chain and $\beta^{+}$thalassaemia in which the production of $\beta$ globin chain is reduced ${ }^{(2)}$. Iron overload causes most of the morbidity and mortality associated with thalassaemia. ${ }^{(3)}$

Two factors are responsible for iron overload in $\beta$ - thalassaemia:

1- Increased intestinal absorption of iron due to erythroid hyperplasia despite tissue iron overload.

2- Transfusional siderosis with up to $200 \mathrm{mg}$ iron is added per packed RBC unit. ${ }^{(4)}$

The iron storage protein, ferritin, plays a key role in iron metabolism.

Its ability to sequester the iron gives ferritin the dual function of iron detoxification and iron reserve. ${ }^{(5)}$

Annual blood consumption was measured by calculating total intake of packed RBC in one year divided by body weight in kilograms, and the resultant unit is $\mathrm{ml}$ of packed $\mathrm{RBC} / \mathrm{kg}$ body weight/year, it had been regarded as a good indicator of iron overload, transfusion scheme and hypersplenism, in which amount in excess of $200 \mathrm{ml} / \mathrm{kg} / \mathrm{year}$ is an indication for splenectomy.$^{(6,7)}$

Patients with thalassaemia major in the early transfusional period need to have serum ferritin levels determined every 1-2 months in order to have a baseline value of iron load to initiate iron chelation therapy which should be started when serum ferritin levels exceeds $1000 \mathrm{ng} / \mathrm{ml}$ and periodic monitoring of serum ferritin every 3 months should be done for patients on iron chelation therapy. ${ }^{(8)}$

\section{Aims of the study}

1- To assess serum ferritin in transfusion dependent $\beta$-thalassaemic patients in Mosul.

2- To establish a correlation between serum ferritin and different clinical, biochemical, and haematological parameters.

3- To determine the efficacy of chelation therapy using desferrioxamine measured by serum ferritin.

\section{Patients and methods}

A total of 100 transfusion dependent $\beta$ thalassaemia patients attending at thalassaemic centre in Ibn-Al Atheer paediatric hospital in Mosul, $52 \%$ were males and $48 \%$ were females for regular blood transfusions from November 2007 to November 2008 were studied.

History and examination were done for all patients.

The patients were divided into three groups:

1- Patients with good compliance to desferrioxamine therapy (37\%) who took desferrioxamine at a dose of $(20 \mathrm{mg} / \mathrm{kg}$ /day), four times weekly or more by subcutaneous infusion using a special pump.

2- Patients with poor compliance to desferrioxamine therapy (36\%) who took less than four times weekly with variable dose either by subcutaneous infusion or by other route.

3- Patients who didn't receive desferrioxamine therapy at all $(27 \%)$.

No WBC filter was used in all of our patients. 
Ten $\mathrm{ml}$ of venous blood were obtained from each patient immediately before the next blood transfusion.

Three $\mathrm{ml}$ were added to EDTA containing tubes and used for doing complete blood picture and blood film.

The remaining $7 \mathrm{ml}$ of blood sample were collected in a plain tube for serum separation, serum is stored at - 20 degrees centigrade for estimation of serum ferritin and performing hepatitis screen later.

All investigations were done according to standard methods. $^{(9)}$

\section{Results}

Age of patients was in the range of (2-29) years with a mean age of 8 years, $72 \%$ of patients were 10 years or younger.

Regarding weight for age distribution of our patients, compared to $5^{\text {th }} \%$ of the general population, $37 \%$ of our patients were found to be under weight $(p<0.001)$.

Regarding height for age distribution of thalassaemic patients, compared to $5^{\text {th }} \%$ of the general population $57 \%$ of patients in the study were found to be of short stature for age $(p<0.001)$.

Control for serum ferritin was done on 30 normal children and adults of the same age and sex of the patients and the mean of serum ferritin was found to be $28.66 \mathrm{ng} / \mathrm{ml}$ ranging between 8 and $144 \mathrm{ng} / \mathrm{ml}$.

The mean value of serum ferritin in all 100 transfusions dependent $\beta$-thalassaemia patients was $1886.74 \mathrm{ng} / \mathrm{ml}$ with a range of $380-7990 \mathrm{ng} / \mathrm{ml}$

For degree of association between serum ferritin and different parameters, it was found that increasing age of patients and number of blood transfusions to date were found to be associated with increased serum ferritin level.

Figure (1): Histogram shows age and sex distribution of our patients, age of patients was in the range of (2-29) years with a mean age of 8 years, $72 \%$ of patients were 10 years or younger.

Figure (2): Scatter diagram shows relation between serum ferritin and age of the patients, a positive correlation was established $(p<0.02)$ and $(r=0.233)$.
Figure (3): Scatter diagram shows a positive correlation between number of blood transfusions to date and increased serum ferritin, $(p<0.001)$ and $(r=0.365)$.

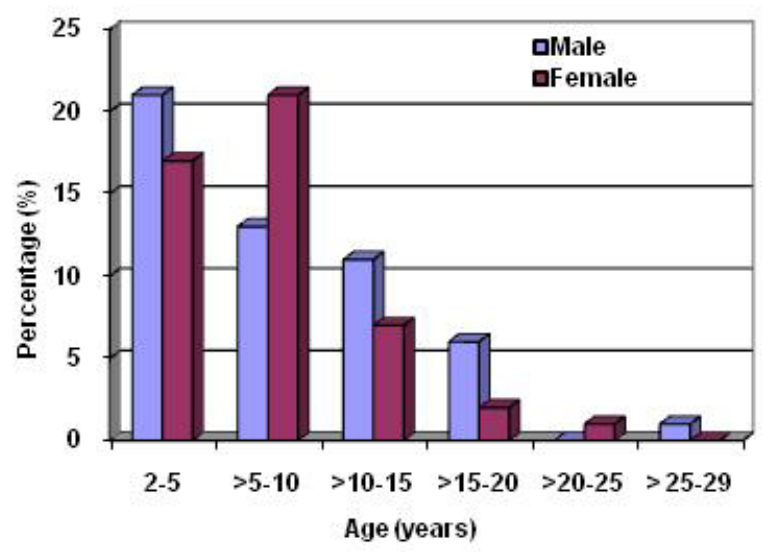

Figure (1): Histogram shows age and sex distribution of patients in the study.

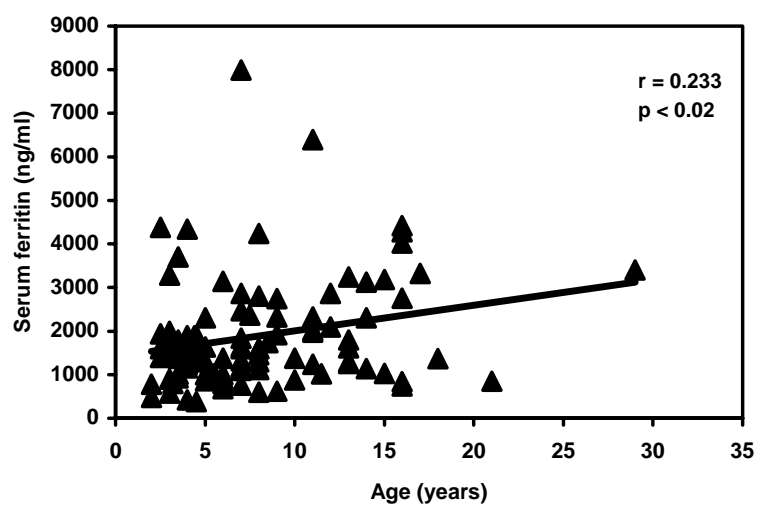

Figure (2): Scatter diagram shows relation between serum ferritin and age of patients in years.

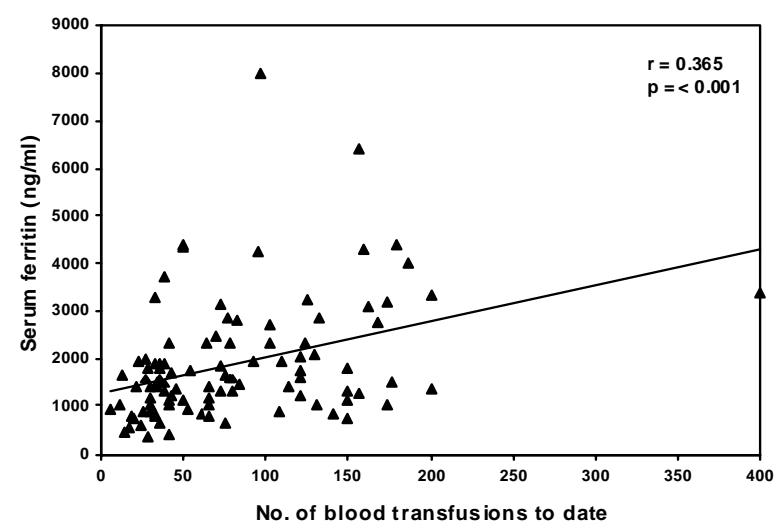

Figure (3): Scatter diagram shows relation between serum ferritin and number of blood transfusion to date. 
Figure (4): Scatter diagram shows that increased annual blood consumption is directly associated with increased serum ferritin level $(p<0.05)$ and $(r=0.212)$.

Table (1): On grouping of patients according to serum ferritin level into 2 groups, those below $2500 \mathrm{ng} / \mathrm{ml}$ and those equal to or more than $2500 \mathrm{ng} / \mathrm{ml}$ and comparison between them, it was found that patients with serum ferritin equal to or above $2500 \mathrm{ng} / \mathrm{ml}$ were older than those below $2500 \mathrm{ng} / \mathrm{ml}$, and had significantly short stature for their age when compared to patients with serum ferritin less than $2500 \mathrm{ng} / \mathrm{ml}$.

Figure (5): Diagram shows distribution of patients compliance to desferrioxamine with regard to serum ferritin with higher serum ferritin in patients with poor compliance when compared to patients with good compliance ( $p$ $<0.05$ ).

Mean serum ferritin in all patients using desferrioxamine was $2043 \mathrm{ng} / \mathrm{ml}$ with a mean age of (9.44) years, and significantly $(P<0.05)$ higher than mean serum ferritin in patients not started using desferrioxamine with a very young age, the mean age was (3.4) years and serum ferritin mean was $1462.96 \mathrm{ng} / \mathrm{ml}$.

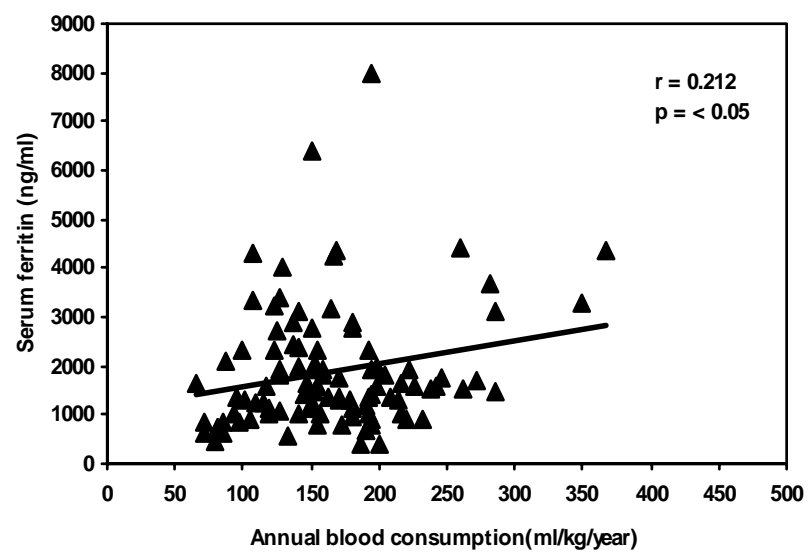

Figure (4): Scatter diagram between serum ferritin level and annual blood consumption.

Table (1): Grouping of patients with transfusion dependent $\beta$-thalassaemia according to $S$. ferritin level and comparison between their different parameters.

\begin{tabular}{|c|c|c|c|}
\hline \multirow[b]{2}{*}{ Parameters } & \multicolumn{2}{|c|}{ Serum ferritin (ng/ml) } & \multirow[b]{2}{*}{ P-value } \\
\hline & $\begin{array}{c}<2500 \\
\text { No. of patients }(79) \\
\text { Range } 380-2460 \\
\text { Mean } \pm \text { SD } 1369.80 \pm 510.09\end{array}$ & $\begin{array}{c}\geq 2500 \\
\text { No. of patients }(21) \\
\text { Range } 2740-7990 \\
\text { Mean } \pm \text { SD } 3831.43 \pm 1285.31\end{array}$ & \\
\hline $\begin{array}{l}\text { Age(years) } \\
\text { Range } \\
\text { Mean } \pm \text { SD }\end{array}$ & $\begin{array}{c}2-21 \\
7.18 \pm 4.13\end{array}$ & $\begin{array}{c}2.5-29 \\
11.32 \pm 6.64\end{array}$ & $<0.001$ \\
\hline $\begin{array}{l}\text { Height for age growth } \\
\text { retardation (short stature) } \\
\text { No } \\
\%\end{array}$ & $\begin{array}{c}42 \\
53.16\end{array}$ & $\begin{array}{c}15 \\
71.43\end{array}$ & $<0.001$ \\
\hline $\begin{array}{l}\text { Splenectomy } \\
\text { No } \\
\% \\
\end{array}$ & $\begin{array}{c}9 \\
11.39 \\
\end{array}$ & $\begin{array}{c}5 \\
23.8 \\
\end{array}$ & $<0.001$ \\
\hline $\begin{array}{l}\text { Number of blood transfusions } \\
\text { to date } \\
\text { Range } \\
\text { Mean } \pm \text { SD }\end{array}$ & $\begin{array}{c}5-200 \\
67.72 \pm 46.69\end{array}$ & $\begin{array}{c}96-156 \\
131.33 \pm 84.53\end{array}$ & $<0.001$ \\
\hline $\begin{array}{l}\text { Annual blood consumption } \\
\mathrm{ml} / \mathrm{kg} / \mathrm{yr} \\
\text { Range } \\
\text { Mean } \pm \mathrm{SD}\end{array}$ & $\begin{array}{c}65.47-285.38 \\
159.63 \pm 51.46\end{array}$ & $\begin{array}{c}106.38-367.92 \\
185.54 \pm 77.14\end{array}$ & $<0.05$ \\
\hline
\end{tabular}

Independent samples T test was used. 


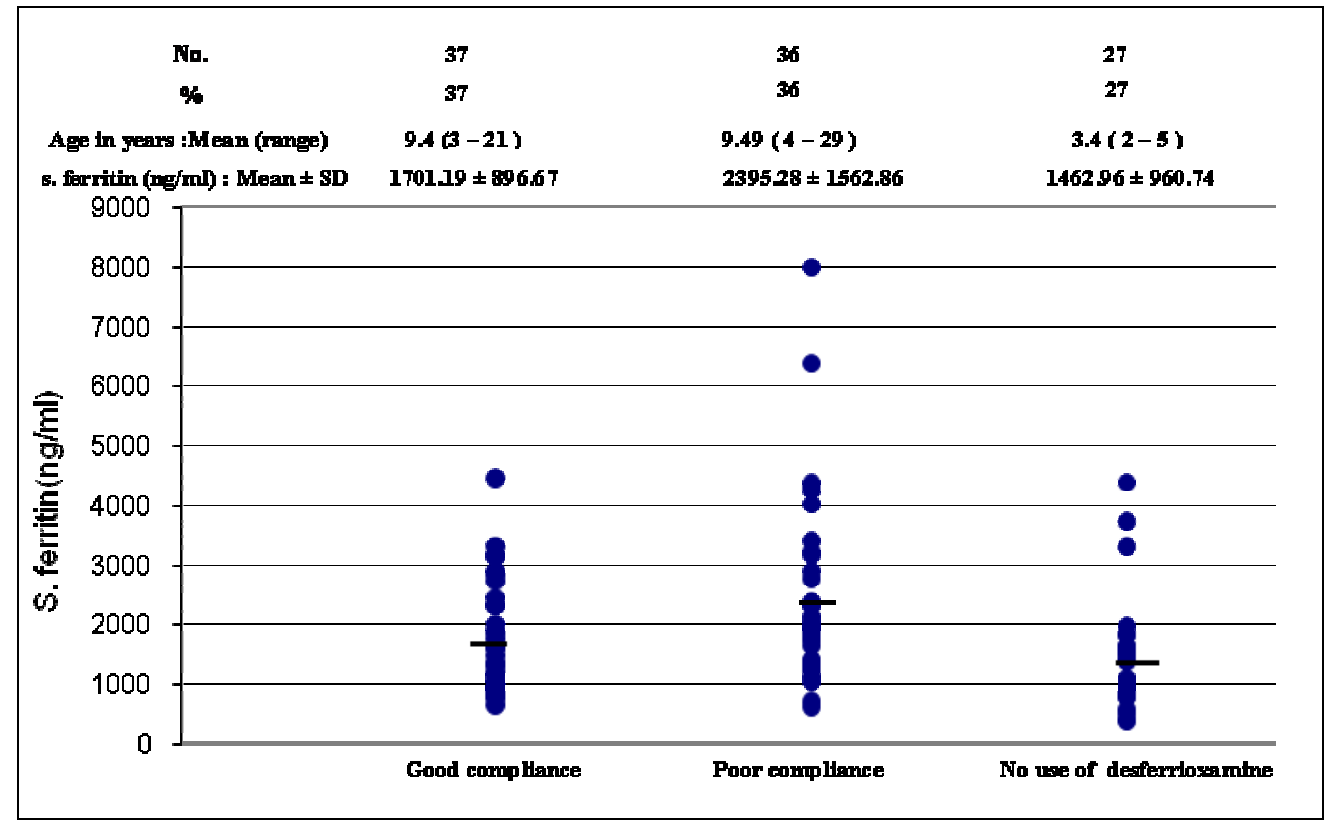

Figure (5): Distribution of patients compliance to desferrioxamine with regards to $\mathrm{S}$. ferritin level (Total no. of patients on desferrioxamine was 73).

Regarding some of the complications, 2 male patients were diabetics, aged 16 and 29 years and both were splenectomised.

They were both on insulin, but their random blood glucose was within normal range, serum ferritin of one of them was $1740 \mathrm{ng} / \mathrm{ml}$, the other patient serum ferritin was $3400 \mathrm{ng} / \mathrm{ml}$.

Table (2): This table shows a statistically significant increased hepatitis $C$ infection in our patients compared to normal Iraqi population $(p<0.001)$.

Table (2): Comparison of hepatitis between patients in the study and Iraqi population.

\begin{tabular}{|l|c|c|c|}
\cline { 2 - 4 } \multicolumn{1}{c|}{} & $\begin{array}{c}\text { Hepatitis } \\
\text { B } \\
\text { (HBsAg) }\end{array}$ & $\begin{array}{c}\text { Hepatitis C } \\
\text { (HCV } \\
\text { Antibodies) }\end{array}$ & $\begin{array}{c}\text { Concomitant } \\
\text { Hepatitis B } \\
\text { and C }\end{array}$ \\
\hline $\begin{array}{l}\text { Patients in } \\
\text { the study \% }\end{array}$ & 1 & 16 & 1 \\
\hline $\begin{array}{l}\text { Prevalence in } \\
\text { Iraqi } \\
\text { population } \\
\text { (\%) }\end{array}$ & $2-3^{*}$ & $0.5^{*}$ & $0^{* *}$ \\
\hline
\end{tabular}

* Reference 10

** Reference 11

\section{Discussion}

Results of serum ferritin were significantly correlated with both advancing age of the patients (figure 2) and increased number of blood transfusion to date (figure 3) which is comparable to those of Shanna study. ${ }^{(12)}$

Carnelli et al and Cario et al studies also found that serum ferritin values correlates to total amount of blood transfusions. ${ }^{(13,14)}$

Close to our results, Cario et al found that $(75 \%)$ of patients younger than 10 years had serum ferritin less than $1800 \mathrm{ng} / \mathrm{ml}$ while $(52 \%)$ of thalassaemic patients who were older than 10 years had serum ferritin above 2500 $\mathrm{ng} / \mathrm{ml} .^{(14)}$

Short stature was found in $71.43 \%$ of transfusion dependent $\beta$-thalassaemia patients with serum ferritin equal or above $2500 \mathrm{ng} / \mathrm{ml}$ compared to $(53.16 \%)$ of short stature in patients with serum ferritin below $2500 \mathrm{ng} / \mathrm{ml}$, similar findings were repeated in Moayeri et al study who showed that short stature is common in thalassaemic patients with serum ferritin above $2000 \mathrm{ng} / \mathrm{ml}$; he relates this to suboptimal chelation therapy leading to high serum ferritin level with iron deposition and damage to hypothalamic pituitary axis and growth failure. ${ }^{(15)}$ 
Also Shalitin et al suggested that a cutoff point of $3000 \mathrm{ng} / \mathrm{ml}$ serum ferritin during the first decade of life predict final short stature. ${ }^{(16)}$

Mean serum ferritin is lower in patients with good compliance to desferrioxamine (DFO) when compared to patients with poor compliance $(p<0.05)$ (figure 4$)$ indicating the beneficial effect of proper chelation therapy in reducing mean serum ferritin level.

The same was found by Kattamis et al ${ }^{(17)}$ and Richardson et al . ${ }^{(18)}$

Patients not started using DFO had significantly lower mean serum ferritin values $1462.96 \mathrm{ng} / \mathrm{ml}$ compared to both groups on DFO therapy those with good compliance to DFO (mean serum ferritin of $1701.19 \mathrm{ng} / \mathrm{ml}$ ) and those with poor compliance to desferrioxamine therapy with a mean serum ferritin of $2395.28 \mathrm{ng} / \mathrm{ml}$.

The probable cause for this lower mean serum ferritin value in the group of patients not started using desferrioxamine was the younger mean age of these patients compared to other groups on desferrioxamine therapy (3.4 years mean age of patients not use desferrioxamine versus 9.4 years in patients with compliance and 9.49 years in patients with poor compliance to desferrioxamine respectively).

Many studies showed that $2500 \mathrm{ng} / \mathrm{ml}$ serum ferritin is a cut point of prognosis with higher incidence of cardiac complication and shortened survival in those above $2500 \mathrm{ng} / \mathrm{ml}$ compared to those below $2500 \mathrm{ng} / \mathrm{ml} .^{(19,20)}$

Short stature was found in $71.43 \%$ of transfusion dependent $\beta$-thalassaemia patients with serum ferritin equal or above $2500 \mathrm{ng} / \mathrm{ml}$ compared to $53.16 \%$ of short stature in patients with serum ferritin below $2500 \mathrm{ng} / \mathrm{ml}$, similar findings were reported in Moayeri et al study who showed that short stature is common in thalassaemic patients with serum ferritin above $2000 \mathrm{ng} / \mathrm{ml}$, he relates this to suboptimal chelation therapy leading to high serum ferritin level with iron deposition and damage to hypothalamic pituitary axis and growth failure. ${ }^{(15)}$

In the current study splenectomised patients have higher ferritin mainly because those patients were older than non splenectomised and received more units of total blood transfusion.

Annual blood consumption is significantly higher in transfusion dependent $\beta$ thalassaemia patients with serum ferritin above $2500 \mathrm{ng} / \mathrm{ml}$ when compared to those below $2500 \mathrm{ng} / \mathrm{ml}$, because increased blood intake per body weight is associated with increased iron overload.

Because of early accelerated schedule for hepatitis $B$ vaccination which starts at the time of registration in thalassaemic centre and administration of booster doses of hepatitis $B$ vaccine, the prevalence of hepatitis $B$ in our patients is even less than those of general population.

However, up to $16 \%$ of our patients were infected by hepatitis $\mathrm{C}$.

This result was similar to that of Dawaj study on thalassaemic patients in Mosul 2007, where he found that $17 \%$ of patients had hepatitis $C$ infection. ${ }^{(21)}$

These results of hepatitis $\mathrm{C}$ infection in thalassaemic patients were high when compared to $0.5 \%$ incidence of hepatitis $C$ in Iraqi population. ${ }^{(22)}$

It appears clearly that the unavailability of vaccination to hepatitis $C$ and the use of non screened blood bags during sanction against Iraq in the nineties of the previous century till 2003 increased the incidence of hepatitis $C$ in our thalassaemic patients.

\section{Conclusions}

1. Growth retardation regards weight for age and height for age was found in $37 \%$ and $57 \%$ of our patients respectively.

2. Increasing age of the patients, number of blood transfusions to date and annual blood consumption were found to be associated with increased serum ferritin level.

3. By grouping patients into two groups those with serum ferritin below $2500 \mathrm{ng} / \mathrm{ml}$ and those with serum ferritin equal or above $2500 \mathrm{ng} / \mathrm{ml}$, it was found that patients with serum ferritin equal or more than 2500 $\mathrm{ng} / \mathrm{ml}$ were of shorter stature, had greater percentage of splenectomy, received higher number of blood transfusions and were of higher annual blood consumption 
than patients with serum ferritin less than $2500 \mathrm{ng} / \mathrm{ml}$.

4. Compliance of patients to chelation therapy was directly correlated to serum ferritin level with higher serum ferritin in patients with poor compliance.

5. Patients not using desferrioxamine had lower mean age and lower mean serum ferritin than patients using desferrioxamine.

\section{References}

1. David HK. Thal for thal?, Blood 2007; 110 (8): 2788.

2. Provan D. $A B C$ of clinical haematology, $2^{\text {nd }}$ ed., BMJ books 2003;11.

3. Gardenghi S, Marongiu MF, Ramos $P$, et al. Ineffective erythropoiesis in $\beta$ thalassemia is characterized by increased iron absorption mediated by downregulation of hepcidin and up-regulation of ferroportin, Blood 2007;109(11): 5035.

4. Rund D, Rachmilewitz E. $\beta$-thalassemia, $N$ Eng J Med. 2005; 353: 1135-1139.

5. Hoffbrand AV, Catovsky D, Tudenham EG. Postgraduate haematology, $5^{\text {th }}$ ed., Blackwell publishing 2005; 88-90.

6. Al-Awamy BH. Thalassemia syndromes in Saudi Arabia, meta-analysis of local studies, Saudi Med J 2000; 21(1): 13.

7. Origa $R$, Bina $P$, Agus $A$, et al. Combined therapy with deferiprone and desferrioxamine in thalassemia major, Haematologica 2005; 90:1309.

8. Angelucci E, Barosi G, Camaschella C, et al. Italian society of hematology practice guidelines for the management of iron overload in thalassemia major and related disorders, Haematologica 2008;93(5): 742.

9. Lewis SM and Bain BJ, Dacie and Lewis practical haematology, $9^{\text {th }}$ ed., Churchill Livingstone 2004; 34-39,44,60.

10. Hepatitis C in Iraq, Ministry of health, Center of disease control, Bulletin of endemic disease, 2004; 31: 1.

11. Awad MH. Homozygous beta thalassaemia in Mosul, Ph.D thesis in pathology (haematology), college of medicine, Mosul, Iraq, 1999; 31-33.

12. Shaana RK. Relationship between serum ferritin and number of blood transfusions in minimally chelated thalassaemia patients in the Erbil city of Iraq, 2007, A thesis of fellowship of Iraqi board of medical specialization in pathology : 22 .

13. Carnelli V, D'Angelo E, Pecchiari M, et al. Pulmonary dysfunction in transfusiondependent patients with thalassemia major, Am J Respir Crit Care Med 2003; 168: 180-183.

14. Cario H, Stahnke K, Sander S, et al. Epidemiological situation and treatment of patients with thalassemia major in Germany: Results of the german multicenter $\beta$-thalassemia study,Ann Hematol 2000; 79(1):7.

15. Moayeri H, Oloomi Z. Prevalence of growth and puberty failure with respect to growth hormone and gonadotropins secretion in beta-thalassemia major, Arch Iranian Med 2006; 9 (4): 329.

16. Shalitin $S$, Weintrob $D$, Carmi $N$, et al. serum ferritin level as a predictor of impaired growth and puberty in thalassemia major patients, Eur J Haematol 2005;74:93.

17. Kattamis A, Dinopoulos A, Ladis V, et al. Variations of ferritin levels over a period of 15 years as a compliance chelation index in thalassemic patients, American J hemat 2001; 68(4):221.

18. Richardson ME, Matthews RN, Alison JF, et al. Prevention of heart disease by subcutaneous desferrioxamine in patients with thalassaemia major, Aust $\mathrm{N} \mathrm{Z} \mathrm{J}$ Med1993; 23(6):656.

19. Silvilairat $S$, Sittiwangkul $R$, Pongprot $Y$, et al. Tissue doppler echocardiography reliably reflects severity of iron overload in pediatric patients with $\beta$ thalassemia, Eur $\mathrm{J}$ Echocardiogr 2008; 9(3):368.

20. Olivieri NF, Nathan DJ, MacMillan JH, et al. Survival in medically treated patients with homozygous $\beta$-thalassemia, $\mathrm{N}$ Eng $\mathrm{J}$ Med1994; 331(9):609.

21. Dawaj $M H$, Prevalence of hepatitis $C$ in thalssaemic patients in Mosul, Ph.D. thesis in Microbiology, College of Science, University of Mosul, Iraq, 2007;76.

22. Hepatitis $C$ in Iraq, Ministry of health, Center of disease control, Bulletin of endemic disease, 2004; 31: 1. 